\title{
THE RELATIONSHIP BETWEEN DIMENSIONS OF TECHNICAL KNOWLEDGE OF YOUNG ALPINE SKIING COMPETITORS AND COMPETITIVE PERFORMANCE
}

\author{
Stojan PUHALJ' ${ }^{1}$, Blaž LEŠNIK² \\ ${ }^{1}$ Faculty of Education, Department for Sports training, University of Maribor, Slovenia, \\ ${ }^{2}$ Faculty of Sport, University of Ljubljana \& Ski Instructors and Trainers Association of \\ Slovenia \\ Corresponding Author: \\ Blaž Lešnik \\ University of Ljubljana, Faculty of Sport, Gortanova ul. 22, 1000 Ljubljana, Slovenia \\ Phone: +38641795536 \\ e-mail: blaz.lesnik@,fsp.uni-li,si
}

\section{ABSTRACT}

In the research, the relationship between individual variables of technical assessment of free and competitive style alpine skiing and the criterion variable (competitive performance) are addressed. The criterion variable is the total number of points that was achieved in the Rauch Ski Cup in the season 2013/2014. Twenty selected alpine skiers between the ages of 12 and 14were included in the research. Technical knowledge and tactics of alpine skiing were assessed in the free skiing (TFS) during two giant slalom races for the Rauch Ski Cup (TCS). In order to determine bivariate correlations between the TFS and TFC variables and the competitive performance, the Pearson correlation coefficient method was used. For this particular section of the study, it was confirmed that all the variables used were significantly related to the criterion variable. In the successive test, using the calculation of multiple regression coefficients, we confirmed the high percentage of the explained variance of the two sets of measurements (TFS and TCS). In this research, the influence of technical knowledge of skiing in the free (TFS) and competitive skiing (TCS) on the competitive performance of alpine skiing in Slovenia was studied for the first time. Based on the results of the research, the foundation for both an improved concept of psychophysical and technical training and for the modernization of the selection criteria for the young competitors in alpine skiing will be proposed.

Keywords: alpine skiing, young categories, competitive successfulness, technique in free skiing, technique in competitive skiing. 


\section{POVEZANOST DIMENZIJ TEHNIČNEGA ZNANJA MLADIH TEKMOVALCEV V ALPSKEM SMUČANJU S TEKMOVALNO USPEŠNOSTJO}

\section{IZVLE ČEK}

V raziskavi smo ugotavljali povezavo med posameznimi spremenljivkami pri oceni tehnike alpskega smučanja v prostem in tekmovalnem smučanju s kriterijsko spremenljivko (tekmovalna uspešnost). Slednjo je predstavljal seštevek točk v smučarskem pokalu Rauch v sezoni 2013/14. V raziskavo je bilo vključenih 40 izbranih tekmovalcev alpskega smučanja starih od 12 do 14 let. Področje tehnike in taktike alpskega smučanja je bilo ocenjeno $v$ prostem smučanju (TFS) in na dveh tekmovanjih v veleslalomu za pokal Rauch (TCS). Za določitev bivariatnih povezanosti posameznih spremenljivk TFS in TCS s tekmovalno uspešnostjo smo uporabili metodo izračuna Pearsonovih koeficientov korelacije. V tem delu smo potrdili, da so s kriterijsko spremenljivko statistično značilno povezane vse uporabljene spremenljivke. $V$ nadaljevanju smo s pomočjo izračuna multiplih regresijskih koeficientov potrdili visok odstotek pojasnjene variance obeh sklopov meritev (TFS in TCS). V tej raziskavi je bil v slovenskem prostoru prvič raziskan vpliv tehničnega znanja smučanja v prostem (TFS) in tekmovalnem smučanju (TCS) na uspešnost v tekmovalnem alpskem smučanju. Na osnovi rezultatov raziskave bodo predlagana izhodišča za izboljšan koncept psihofizične in tehnične priprave ter za posodobitev kriterijev za selekcioniranje mladih tekmovalcev in tekmovalk v alpskem sтuс̌anju.

Ključne besede: alpsko smučanje, mlajše kategorije, tekmovalna uspeřnost, tehnika $v$ prostem smučanju, tekmovalna tehnika

\section{INTRODUCTION}

Alpine skiing as an athletic and recreational activity is a small part of global sports. However, in snowy and mountainous regions it is an integral part of the lifestyle of both the young and the old (Krautgasser et al., 2012). This research interest follows the concept of scientific approach in alpine skiing for children in late childhood and in adolescence, exploring some of the factors that influence success in this sport. Alpine skiing is a sport in which success in competitions depends on various internal and external factors that are related to each other (Lešnik \& Žvan, 2003). With the development of skiing disciplines, alpine skiing has reached the level where top results are very hard to reach (Hébert-Losier, Supej, \& Holmberg, 2014). In the process of training, there is a set of different and special elements that are more effective for each discipline in alpine 
skiing (Lešnik et al., 2017). In a multitude of factors that influence the performance of young alpine skiers, technical knowledge of skiing is certainly one of the most important. Based on observations in practice, we find that the skiing technique of young athletes is not on the level that is needed to achieve top results in competitions. The reasons for this, on one hand, are the modes and contents of training that include a lot of skiing between the gates. This, on the other hand, leaves too little time to train the elements of skiing techniques that are outside the ski course setting. As a consequence, many young competitors have a relatively narrow base of skiing skills, and there are many with incorrectly learned movement patterns.

The movements executed during alpine skiing, which involve continuous connecting of short parallel turns, are much more complicated than the movements needed during performance and experimental conditions (Cigrovski et al., 2017). Each skiing turn consists of three phases. The first phase is the beginning of a turn. The second phase is the pivoting phase of a turn, and the third phase is the completion phase (Lešnik \& Žvan, 2010). The most common deficiencies in technical knowledge in younger categories are the imbalance of the body, excessive slipping of the skis throughout the turn, choosing a slower skiing line, and uncoordinated excessive movements during the performances of racing, skiing turns and other technical elements of skiing. All this is becoming one of the main reasons for achieving poorer results in competitions, especially in competitions with more demanding course settings (Lešnik \& Žvan, 2007; Puhalj, 2018).

Special elements of alpine skiing sports techniques correlate highly with the successes and accomplishments in competitive alpine skiing (Loland \& Haugen, 2000). It is important that the development of sporting techniques, psychological potentials and motoric abilities take place simultaneously (Weineck, 2009). Technical elements can be carried out in a series of small partial services or movement patterns which can be connected into a well-functioning technical execution that present quality skiing (LeMaster, 1999). One of the main goals of the ski training technique is stable skiing on the ski edges even in the most difficult conditions. In terms of mastering the technique of skiing, this means constant fine adjustments of body angles, particularly in the hips, knees and ankles, as well as tilting of the body to the side. Distribution of the appropriate strength to complete a turn especially across the fall-line refers to when an increasing gravitational force and resistance develop through extreme inclination of the skis in order to maintain the line of a turn (Wörndle, 2007). In practice, we talk about slipping in turns, which often reflects inadequate or poor technique and pivoting turns on the edges with a good ski grip on a snowy surface (LeMaster, 1999) or, according to Jouberts (1978), for finding quality support on a snowy surface. Development of effective control over the skiing speed and direction can be achieved through a turn on the edges where the front and the rear of the ski slide along the same line of the turn. The skis should only move forward, preferably with zero side slipping and with minimum energy loss (Loland, 2009).

The basic aim of the training of the technique is therefore a balanced, fluid, light and controlled pivoting of skis with appropriate patterns of movement and without 
excessive pressure on the surface. Quality ski training should include both skiing between the gates and skiing outside course settings. It is generally known that a high level of technical knowledge can be achieved primarily through training in a variety of conditions (hard surface, poor visibility, powder skiing and mogul skiing, to name a few). This was also the main starting point for setting up the criteria for the quality technical knowledge of young competitors in alpine skiing (Puhalj, 2018). The so-called Technical Skills Knowledge Model of Young Competitors consists of the variables of the free skiing technique (TFS) and the variables of the technique in competitive skiing between the gates (TCS). Therefore, the main aim of this research is to find out the correlation between the selected variables of skiing technique knowledge and the competitive performance of young athletes in alpine skiing.

\section{METHODS}

The study included 20 young boys (year of birth 2000 and 2001; height $158.97 \mathrm{~cm}$, $+/-9.11 \mathrm{~cm}$; weight $50.18 \mathrm{~kg},+/-9.42 \mathrm{~kg}$ ), all of whom were selected athletes in alpine skiing. The factors of technique in freeride skiing (TFS) that were studied are Balance in Free Skiing (FSBL), Coordination in Free Skiing (FSCO) and Phase of Completing the Turn in Free Skiing (FSCT). The factors of technique in competitive skiing (TCS) that were studied are Technique in Competitive Skiing (CSBL), Balance in Competitive Skiing (CSBL), Phase of Completing the Turn in Competitive Skiing (CSCT) and Lines of Skiing in Competitive Skiing (CSLS).

The evaluation of ski variables of the competition technique for younger boys was carried out during two giant slalom competitions, which also counted for the Rauch Cup. The first competition took place on Soriška planina (March 21, 2014), and the second one in Krvavec (March 29, 2014). In the 30-second starting intervals, the evaluators recorded grades from 1 to 3 on the pre-prepared scoreboards (grade $1=$ poor, $2=$ medium, 3 =good). Both competitions were carried out in ideal snow conditions, which ensured equivalent competitive conditions for all competitors.

The grades of the variables were obtained from 7 members of the National Examination Committee for Alpine Skiing from the Ski Instructors and Trainers Association of Slovenia (SITAS). The grades of the balance assessment (1 to 3) for frequent loss of balance in all four operating directions were marked with the lowest score; the cases of stable balance positions were marked with the highest score. The same evaluation was used in both the competitive and free skiing. Assessment of the pivoting of skis in turns took place under the same criteria in the competitive giant slalom as well as in the giant slalom turns in free skiing with special tasks. Turns with more slipping of the edges were marked with the score 1 and the turns without slipping of the edges were marked with the score 3 . The skiing lines on the medium steep racing tracks, which were carried out with a longer pre-preparation over the gate with a turn above the gate or with a turn below the gate, were rated with the score 1 . Turns with a more direct beginning and completion were rated with the score 3 . Turns a little over and a little below the 
gates (configuration, preparation and ski course setting all considered) were marked with the score 2 . The co-ordination of movements was assessed only in free skiing and was based on harmonic, timely and spatially coordinated uninterrupted movements from one turn to another. The moving phases followed each other slower downwards and faster upwards. Special attention was also paid to the coordinated pole planting, which also marked the beginning of the vertical movement. This was absolutely necessary when passing from one turn to another on the lower ski with a lifted upper ski. A score of 3 was assigned for a well-coordinated movement from one turn to another and a score of 1 for uncoordinated movement (Puhalj, 2018).

The Pearson correlation coefficient method was used to calculate the correlation between individual variables and the criterion variable (achieved points in the Rauch Ski Cup for the season 2013/14). On the basis of certain components, consisting of free skiing (TFS) and competitive skiing between the gates variables (TCS), we also calculated the percentage of the explained variance.

The criterion variable represents competitive performance at the highest degree of children's competitions in alpine skiing organized under SAS. Ranking level at competitions (criterion variable) for each competitor is calculated on the basis of the sum of official results (SAS, 2010).

\section{RESULTS AND DISCUSSION}

The analysis of the correlation between variables of the technique in free skiing (TFS) and the variables of the technique in competitive skiing (TCS) shows a statistically significant correlation with the criterion variable (success in the Rauch Cup). As a rule, the participants of the study who received higher scores for their skiing technique also achieved a higher ranking in the competitions for the Rauch Cup.

Table 1 shows the association of all three variables of the free skiing technique skills and the performance in competitions at the level of a $1 \%$ risk. The coordination in free skiing variable runs the highest level of association with the performance in competitions $\left(\mathrm{r}_{\mathrm{FSCO}}=0.762^{* *}\right)$. An almost as high correlation was calculated for the variables of balance in free skiing $\left(\mathrm{r}_{\mathrm{FSBL}}=0.728^{* *}\right)$ and for the variable quality completing the turn in free skiing $\left(\mathrm{r}_{\mathrm{FSCT}}=0.601^{* *}\right)$. The three variables considered together account for as much as $83 \%$ of the variance area of the component of the technique in free skiing (TFS), which means that the selected criteria for determining and checking the technique of young competitors in free skiing is appropriate. Statistically high significant correlations between the components of the technique in free skiing indicate that the training elements of free skiing techniques are a very important part of training for young competitors. Therefore, in the future, during snow training, trainers will have to spend more time conducting training for balance, coordination and skiing turns in freeride skiing. All these elements of skiing techniques are closely interconnected and, as such, provide a quality performance of skiing turns, which form the basis of the competition skiing style. An important reason for increasing the amount of the skiing 
Table 1: Calculation of Pearson's coefficients between individual variables of the technique in free skiing (TFS) and technique in competitive skiing (TCS), and criterion variable, and percentage of explained variance of main component in free skiing (FSEV $\%)$ and in competition skiing (CSEV\%).

\begin{tabular}{|c|c|c|c|c|c|c|c|}
\hline TFS & $\mathbf{N}$ & $\mathbf{A V}$ & SD & $\mathbf{r}$ & $h^{2}$ & $\Lambda$ & $\% \mathrm{EV}$ \\
\hline FSBL & 20 & 6.55 & 1.669 & $.728 * *$ & 0.745 & & $\begin{array}{c}\left(\begin{array}{c}\text { F S E V } \\
\%)\end{array}\right. \\
\end{array}$ \\
\hline FSCO & 20 & 7.10 & 1.518 & $.762 * *$ & 0.928 & 2.494 & 83.140 \\
\hline FSCT & 20 & 7.05 & 1.731 & $.601 * *$ & 0.821 & & \\
\hline TCS & $\mathbf{N}$ & $\mathbf{A V}$ & SD & $\mathbf{r}$ & $h^{2}$ & $\Lambda$ & $\% \mathrm{EV}$ \\
\hline CSBL & 20 & 10.75 & 1.803 & $.613^{* *}$ & 0.683 & & $\begin{array}{c}\left(\begin{array}{c}C S \\
\%\end{array}\right) \\
0\end{array}$ \\
\hline CSCT & 20 & 13.05 & 2.328 & $.743 * *$ & 0.814 & 2.188 & 72.940 \\
\hline CSLS & 20 & 11.75 & 2.337 & $.506^{*}$ & 0.691 & & \\
\hline
\end{tabular}

Legend: TFS-Technique in free skiing; FSBL-Balance in free skiing; FSCO-Coordination in free skiing; FSCT-phase of completing the turn in free skiing; TCS-technique in competitive skiing; CSBL-Technique in competitive skiing; CSCT- phase of completing the turn in competitive skiing; CSLS-lines of skiing in competitive skiing; $N$-number of competitors; AV-average result; $S D$-standard deviation; $r$-Person's coefficient of correlation with criterion variable; *- statistical significance of $r$ on $5 \%$ risk level; ${ }^{* *}$ - statistical significance of $r$ on $1 \%$ of risk level; h2-main component comunality; $\lambda$ - main component value; $\% E V-\%$ of explained variance; $F S E V \%$ - $\%$ of explained variance of main component in free skiing; CSEV\%- \% of explained variance of main component in competition skiing.

technique training in free skiing is that it also allows for the diversification of training on snow. Special exercises based on atypical motor structures can be a good variation of training on snow, which in turn can have a positive impact on the technical knowledge of skiing (Lešnik \& Žvan, 2010). The acquisition of technical skills for young athletes, along with quality physical conditioning, is very important because over the years all the missing technical knowledge becomes increasingly difficult to correct and the imbalances more difficult to adjust (Raschner, Müller, \& Hildebrandt, 2015).

Among the 3 variables of the competition technique of skiing between the gates (TCS), the completing the turn variable $\left(\mathrm{r}_{\mathrm{CSCT}}=0.743 * *\right)$ is strongly associated with the competition performance, while the balance variable is slightly less associated with it $\left(\mathrm{r}_{\mathrm{CSBL}}=0.613^{* *}\right)$. Both connections are statistically significant at the level of a $1 \%$ risk. The third considered variable, which determines the quality of the selected turning line, is the least connected with success in competitions, but is still statistically significant at the level of a $5 \%$ risk $\left(\mathrm{r}_{\mathrm{CSLS}}=0.506^{*}\right)$. The three variables presented in total explain 
$73 \%$ of the space variance of the competition technique of skiing between the gates component (TCS), which means that the selected criteria for identifying and assessing the technique of young competitors in the competition ski course setting are appropriate. Stable skiing on the edges means constant fine-tuning of body angles in the hips, knees and ankles, as well as tilting of the body to the side. All the measured parameters of the technique are considered to be crucial for the competition results in alpine skiing (Wörndle, 2007; Loland, 2009).

In accordance with the results, the competitors with a better balance on the skis, a cleaner turn performance and a better selected and a faster line of the turn were ranked higher in the competitions for the Rauch Cup 2014/15. Therefore, these segments of competitive skiing techniques will require even more attention in the future. At such training, the use of various didactic tools, such as markers, cones and other aids (Pišot \& Videmšek, 2004) is crucial in helping athletes balance the position of the body, as well as limit the time and length of a turn and the line throughout an entire turn (Lešnik \& Žvan, 2010).

The main finding of this research is that all the selected variables for checking and determining the quality of the technique of young, skiing competitors in alpine skiing are significantly related to the criterion variable (competition performance). Particularly interesting is the fact that the highest degree of association with the criterion is displayed by the variables that are manifested as the most important ones in practice too. Although all the variables used proved to be statistically significant at the highest level of integration, we must, in particular, point out the variable of the coordination of movement in free skiing $\left(\mathrm{r}_{\mathrm{FSCO}}=0.762 * *\right)$, completing the turn between the gates variable $\left(\mathrm{r}_{\mathrm{CSCT}}=0.743 * *\right)$ and the balance in free skiing variable $\left(\mathrm{r}_{\mathrm{FSBL}}=0.728 * *\right)$.

In competitive alpine skiing there can be many reasons for losing time; however, from the point of view of skiing technique, one of the main reasons for losing time during the course setting is a poor performance of turns. A good skier performs in a balanced, smooth and effortless manner, ensuring that they have the situation under control through adequate pivoting of skis. Additionally, a good skier's switching between moving patterns is rolling and without excessive pressure on the surface (Loland \& Haugen, 2000). This means that the competitor can lose too much time in the beginning phase of a turn, the pivoting phase as well as in the completion phase of a turn. Slipping of skis, the wrong body position and other unnecessary manoeuvres on the track may also contribute to loss of time. (Sandbakk et al., 2014). In order to keep turns on the edges and optimum arcs of turns, one must use the pressure on the ground very rationally (Loland, 2009). In this respect, the most illustrative is the high correlation between completing the turn between the gates variable $\left(\mathrm{r}_{\mathrm{CSCT}}=0.743 * *\right)$ and the performance. Since only the smallest details distinguish the best competitors from the finest, there are still many reserves in the phase of completing a turn, which must be used with a well-targeted ski training technique. 


\section{CONCLUSION}

The research showed a high degree of correlation between the selected elements of the technique in free and competitive skiing and competitive performance. The latter is especially important when working with younger categories of competitors. However, we must realize that good technical knowledge is only the basis for good tactics in skiing. In different settings of the gates and competition slopes, the straightest route between the two ski gate poles with a short radius of a turn is not always the fastest. Therefore, at competitions, the fastest skiers do not always win. Instead, it is the skiers who lose the least time on the track who are successful (Madura, Lufkin \& Brown, 2012). Researchers recommend an early start of skiing along the fall-line and thus immediate speeding at the beginning of the turning trajectory. The primary force of acceleration is gravitation (Müller \& Schwameder, 2003). Using the 3D kinematical system of measuring and evaluating technical and tactical elements of 16 elite competitors, Supej (2008) also notes that the most direct and the shortest lines in turns are not always the most effective ones. It has been proven that the amplitude of the reaction of the radial force, radii of turns, speed and acceleration are not the only parameters for assessing the quality of skiing, although all these parameters are essential for the competitive alpine skiing. The high speed of the skier at the point of observation does not necessarily mean that the skier is successful because he could slow down the skiing by inappropriate trajectory of turns (Supej, Kugovnik, \& Nemec, 2005). There are turns with a very direct beginning with pivoting and turns with at least $1 / 3$ of the line of a turn performed above the gate. In line with the research of the lines of turns, we can divide them into turns with lines of $50 \%$ above and $50 \%$ below the gate, and on turns with lines of $60 \%$ above and $40 \%$ below the gate. The choice of the most optimal manner of skiing between the gates depends on different factors, especially on weather conditions, treatments of the snow, layout of the racing tracks, disciplines of alpine skiing, configuration of the racing tracks and, of course, physical and technical condition of the competitors. Mainly in the technical disciplines of alpine skiing on steep, configurable demanding fields and with difficult course settings which are dominated by turns with large radii, better racers perform skiing lines with early ski edging and transfer weight on the outside ski. They also have more turn performance above the gates than beneath them (Brodie, 2009).

On the way to achieving good results in alpine skiing, strengthening of the psychomotor base and development of motor control processes are largely linked to ski coordination. In previous research, it has been repeatedly found that general and special co-ordination have the greatest influence on the efficiency of the movement of young competitors (Bandalo, 2016; Pišot, Kipp, \& Supej, 2010). Malina and Bouchard (1991) also find high association between the biological age (bone age) and motor abilities and skills in conjunction with high muscular force. In the process of acquiring ski knowledge, this is especially reflected in practice. Acquisition of basic ski skills begins through practice of the basics of the free skiing technique (Mildner et al., 2012). Only later are the acquired knowledge and skills gradually upgraded on the set-up ski courses. 
Weineck (2009) also defines a theory of gradualism in acquiring motor skills (which include also technical knowledge) over a 4-tier scale. Therefore, we gradually approach the situation in competitions where measured time is the only performance parameter.

In the age group covered by the sample, the efficiency of movement is also associated with developmental changes (Grosser, Starischka \& Zimmermann, 2004). Accelerated growth can greatly aggravate movement and the entire training process needs to be adapted to it (Pernitsch \& Staudacher, 1998). In the study, there were many cases where competitors were unable to achieve top-level results because of a poorly developed co-ordination capability. Due to high demands for development of special motor skills (Pišot, Kipp \& Supej, 2010), mechanical movement analysis is followed by the qualities, where the human body is seen as a system of internal mechanical forces and skiing is seen as the interaction between these forces and the external forces connected with the environment (Supej et al., 2005). According to the findings, the physical self-concept is more closely connected with body composition and morphologic features in boys than in girls, whereas the body fat proportion is the strongest predictor of physical self-concept in boys. The findings show that, particularly in boys, the physical self-concept is also largely based on the morphologic features and body composition (Puhalj, Matejek, \& Planinšec, 2013).

In the research, the influence of technical knowledge of skiing in free and competitive skiing in comparison to the competitive performance in alpine skiing has been explored and it has shown a high degree of integration. Research findings of this study are an important confirmation for systematic integration of the training of skiing techniques into the training process of younger categories in alpine skiing. Based on the research results, the necessary conditions for devising exercise, the establishment of new criteria for selecting children, and the prediction of the likelihood of sports results in alpine skiing for the selected sample of children will be suggested with orientations for a more friendly and athletic-focused approach.

\section{REFERENCES}

Bandalo, M. (2016). Dinamika sprememb morfoloških in motoričnih dimenzij mladih tekmovalcev v alpskem smučanju v obdobju od leta 2001 do 2010 [Dynamics of morphological and motor dimensions variations in young athletes in alpine skiing in the period from 2001 to 2010] (Unpublished doctoral dissertation). Ljubljana: University of Ljubljana, Faculty of sport.

Brodie, M. A. D. (2009). Development of Fusion Motion Capture for Optimisation of Performance in Alpine Ski Racing (Doctoral dissertation). Massey University, Wellington. Retrieved from https://mro.massey.ac.nz/bitstream/handle/10179/1041/02whole.pdf

Cigrovski, V., Franjko, I., Rupčić, T., Baković, M., \& Božič, I. (2017). Is specific motor test enough to evaluate new alpine ski knowledge in ski beginners? Annales Kinesiologiae, 8(1), 5-14. VIEW ITEM 
Grosser, M., Starischka, S., \& Zimmermann, E. (2004). Das neue Konditionstraining: Grundlagen, Methoden, Leistungssteuerung, Übungen, Trainingsprogramme (BLV Sportwissen). München: BLV Verlagsgesellschaft $\mathrm{GmbH}$.

Hébert-Losier, K., Supej, M., \& Holmberg, H. C. (2014). Biomechanical factors influencing the performance of elite Alpine ski racers. Sports Medicine, 44(4), 519-533. DOI: $10.1007 / \mathrm{s} 40279-013-0132-z$ VIEW ITEM

Joubert, G. (1978). Skiing - An Art, a Technique. Boulder, CO: Poudre Press.

Krautgasser, S., Scheiber, P., Von Duvillard, S., \& Müller, E. (2012). Heart rate, Mood States, and rating of perceived exertion among elderly subjects during 3.5 hours of recreational alpine skiing. Annales Kinesiologiae, 3(2), 167-180. VIEW ITEM

LeMaster, R. (1999). The Skier's Edge. Champaign (USA): Human Kinetics.

Lešnik, B. \& Žvan, M. (2003). Comparison of centre of mass trajectories in modern giant slalom techniques. Kinesiology, 35(2), 191-200.

Lešnik, B. \& Žvan, M. (2007). The best slalom competitors - kinematic analysis of tracks and velocities. Kinesiology 39(1), 40-48. VIEW ITEM

Lešnik, B. \& Žvan, M. (2010). A Turn to Move on - Slovenian way of skiing. Ljubljana: Faculty of sport and Ski Instructors Association of Slovenia.

Lešnik, B., Sekulić, D., Supej, M., Esco, M. R., \& Žvan, M. (2017). Balance, basic anthropometrics and performance in young alpine skiers: longitudinal analysis of the associations during two competitive seasons. Journal of Human Kinetics, 57(1), 7-16. doi: 10.1515/hukin-2017-0042 VIEW ITEM

Loland, S., \& Haugen, P. (2000). Alpin skiteknikk. Oslo: Norges Idrettshǿgskole.

Loland, S. (2009). Alpine skiing technique - Practical knowledge and scientific analysis. In E. Müller, S. Lindinger, \& T. Stöggl (Eds.), Science and Skiing IV, (pp. 43-58). Oxford: Meyer \& Meyer.

Madura, J. M., Lufkin, T., \& Brown, C. A. (2012). Calculated descent times for different radii in ski racing. In E. Müller, S. Lindinger, \& T. Stöggl (Eds.), Science and Skiing V, (pp. 263 - 271). Oxford: Meyer and Meyer Sport.

Malina, R. M., \& Bouchard, C. (1991). Growth, maturation and physical activity. Champaign (USA): Human Kinetics.

Mildner, E., Barth, M., Ehn, G., Kriebernegg, R., Staudacher, A., \& Raschner, C. (2012). Relationship between physical fitness, ski technique and racing results of young alpine ski racers. In E. Müller, H. Schwameder, E. Kornexl, \& C. Raschner (Eds.). Proceedings book of The first international Congress on Skiing and Science (pp. 282-290). Salzburg: Austrian Association of Sports Sciences and University of Salzburg.

Müller, E., \& Schwameder, H. (2003). Biomecanical aspects of new techniques in alpine skiing and ski-jumping. Journal of Sports Sciences, 21(9), 679-692. doi: 10.1080/0264041031000140284 VIEW ITEM

Pernitsch, H., \& Staudacher, A. (1998). Konditions-training im alpinen Skirennlauf. Insbruck: Österreichische Skiverband.

Pišot, R., \& Videmšek, M. (2004). Smučanje je igra. Ljubljana: Združenje učiteljev in trenerjev smučanja Slovenije.

Pišot, R., Kipp, R., \& Supej, M. (2010). Skiing is a game, Koper: Univerza na Primorskem, Znanstveno raziskovalno središče Koper - Inštitut za kineziološke raziskave, Univerzitetna Založba Annales.

Puhalj, S. (2018). Vrednotenje uspešnosti tekmovalnega alpskega smučanja v obdobju poznega otroštva in adolescence [Evaluation of the performance of alpine ski racing 
in late childhood and adolescence] (Unpublished doctoral dissertation). University of Primorska, Faculty of Health Sciences, Applied Kinesiology, Koper.

Puhalj, S., Matejek, Č., \& Planinšec, J. (2013). Physical, self-concept, anthropometry and body composition in preadolescents. Annales Kinesiologiae, 4(1), 17-28. VIEW ITEM

Raschner, C., Müller, L., \& Hildebrant, C. (2015). Talent detection and development in Alpine skiing. In E. Müller, S. Lindinger, \& T. Stöggl (Eds.), Science and Skiing IV, (pp. 65 - 75). Oxford: Meyer \& Meyer.

Sandbakk, Ø., Bucher Sandbakk, S., Supej, M., \& Holmberg, H.-C., (2014). The velocity and energy profiles of elite cross-country skiers executing downhill turns with different radii. International Journal of sports Physiology \& Performance, 9(1), 41-47. doi: 10.1123/IJSPP.2013-0383 VIEW ITEM

Supej, M., (2008). Differential specific mechanical energy as a quality parameter in racing alpine skiing. Journal of Applied Biomechanics, 24(2), 121-129. doi: 10.1123/ jab.24.2.121 VIEV ITEM

Supej, M., Kugovnik, O., \& Nemec, B. (2005). Advanced analysis of skiing based on 3D kinematic measurements. In E. Müller, D. Bacharach, R. Klika, S. Lindinger, \& H. Schwameder, (Eds.) Science and Skiing III. (pp. 216-227). Oxford: Meyer \& Meyer Sport (UK).

SAS - Ski Association of Slovenia (2010). Competitions in alpine skiing. Retrived from http://www.sloski.si/resources/files/pdf/alpsko-smucanje/10-11/slo/alp-sdipok.htm

Weineck, J. (2009). Optimales Training. 16. Aufl. Balingen: Spitta-Verlag GmbH \& Co.

Wörndle, W. (2007). Snowsport Austria. Purkersdorf: Verlags Brüder Hollinek. 